\title{
STRATEGI PENINGKATAN KINERJA PENDIDIK PROFESIONAL BERBASIS ETOS KERJA QUR'ANI
}

\author{
Rosidin \\ Universitas Islam Lamongan (UNISLA), Jl. Veteran 53A Lamongan, Jawa \\ Timur \\ e-mail: mohammed_rosidin@yahoo.co.id
}

\begin{abstract}
This paper is the text of the Koran studies aimed at finding Quranic ethos of the key concepts that could potentially improve the quality of professional educators fourth competence, if implemented optimally. In the process, this article refers to the steps of methodological-applicative interpretation Tarbawi practical: to determine the theme, identify the passages relevant, then analyze the data paragraph with three analytical techniques, namely language (lughawi), content (tahlili) and education (Tarbawi ). There are three main findings of this study. First, the "selfawareness" is a key concept work ethic Qur'ani in improving the performance of professional educators. Details, improvement of professional competence through basic awareness of the obligations of educators; improvement of pedagogical competence through an awareness of the human rights of learners; increase awareness of personal competence through for my own shortcomings; improvement of social competence through awareness of the advantages of others. Second, the implementation strategy of selfawareness in improving the performance of professional educators are theological (faith), theoretical (science), practical (charity) and moralistic (morals). Thirdly, there are three levels of quality implementation of self-awareness, which is below the standard (wrongdoers); according to the standard (muqtashid); and above standard (Sabiq).
\end{abstract}

Keywords: Self-Awareness, Qur'anic Performance, Professional Educators

\begin{abstract}
Abstrak: Tulisan ini adalah studi teks al-Qur'an yang bertujuan menemukan konsep kunci etos kerja Qur'ani yang berpotensi meningkatkan kualitas keempat kompetensi pendidik profesional, jika diimplementasikan dengan optimal. Dalam prosesnya, tulisan
\end{abstract}


ini mengacu pada langkah-langkah metodologis-aplikatif tafsir tarbawi praktis: menentukan tema, mengidentifikasi ayat-ayat yang relevan, kemudian menganalisis data ayat dengan tiga teknik analisis, yaitu kebahasaan (lughawi), isi (tahlili) dan kependidikan (tarbawi). Ada tiga temuan utama penelitian ini. Pertama, "kesadaran diri" merupakan konsep kunci etos kerja Qur'ani dalam meningkatkan kinerja pendidik profesional. Detailnya, peningkatan kompetensi profesional melalui kesadaran atas kewajiban asasi pendidik; peningkatan kompetensi pedagogik melalui kesadaran atas hak asasi peserta didik; peningkatan kompetensi kepribadian melalui kesadaran atas kekurangan diri sendiri; peningkatan kompetensi sosial melalui kesadaran atas kelebihan orang lain. Kedua, strategi implementasi kesadaran diri dalam meningkatkan kinerja pendidik profesional bersifat teologis (iman), teoretis (ilmu), praktis (amal) dan moralistis (akhlak). Ketiga, ada tiga tingkatan kualitas implementasi kesadaran diri, yaitu di bawah standar (zhalim); sesuai standar (muqtashid); dan di atas standar (sabiq).

Kata-Kata Kunci: Kesadaran Diri, Kinerja Qur'ani, Pendidik Profesional

\section{Pendahuluan}

Mendidik merupakan profesi yang terhormat. Namun profesi mendidik selalu rentan untuk dikritik (McNergney, 1981: 7). Inilah prolog untuk membuka bahasan tentang profesi pendidik yang selalu dibutuhkan, namun kerap dijadikan kambing hitam atas problematika yang melanda pendidikan.

Demi meminimalisasi kritik terhadap profesi pendidik, maka diperlukan upaya sungguh-sungguh untuk menyiapkan tenaga didik yang berkualitas. Secara umum, kualitas tersebut mencakup kompetensi pedagogik, kepribadian, sosial dan profesional, sebagaimana ketentuan Peraturan Menteri Pendidikan Nasional (Permendiknas) Republik Indonesia Nomor 16 Tahun 2007 tentang Standar Kualifikasi Akademik dan Kompetensi Guru dan Dosen. 


\section{Tabel 1}

\section{Standar Kualifikasi Akademik dan Kompetensi Guru dan Dosen (Muhaimin, 2011: 191 - 192)}

\begin{tabular}{|c|l|}
\hline No & \multicolumn{1}{|c|}{ Kompetensi Inti } \\
\hline A & Kompetensi Pedagogik \\
\hline 1 & $\begin{array}{l}\text { Menguasai karakteristik peserta didik dari aspek fisik, moral, } \\
\text { spiritual, sosial, kultural, emosional dan intelektual. }\end{array}$ \\
\hline 2 & $\begin{array}{l}\text { Menguasai teori belajar dan prinsip-prinsip pembelajaran yang } \\
\text { mendidik. }\end{array}$ \\
\hline 3 & $\begin{array}{l}\text { Mengembangkan kurikulum yang terkait dengan mata pelajaran } \\
\text { yang diampu. }\end{array}$ \\
\hline 4 & Menyelenggarakan pembelajaran yang mendidik. \\
\hline 5 & $\begin{array}{l}\text { Memanfaatkan teknologi informasi dan komunikasi untuk } \\
\text { kepentingan pembelajaran. }\end{array}$ \\
\hline 6 & $\begin{array}{l}\text { Memfasilitasi pengembangan potensi peserta didik untuk } \\
\text { mengaktualisasikan berbagai potensi yang dimiliki. }\end{array}$ \\
\hline 7 & $\begin{array}{l}\text { Berkomunikasi secara efektif, empatik dan sopan dengan } \\
\text { peserta didik. }\end{array}$ \\
\hline 8 & $\begin{array}{l}\text { Menyelenggarakan penilaian dan evaluasi proses dan hasil } \\
\text { belajar. }\end{array}$ \\
\hline 9 & $\begin{array}{l}\text { Memanfaatkan hasil penilaian dan evaluasi untuk kepentingan } \\
\text { pembelajaran. }\end{array}$ \\
\hline 10 & $\begin{array}{l}\text { Melakukan tindakan reflektif untuk peningkatan kualitas } \\
\text { pembelajaran. }\end{array}$ \\
\hline B & Kompetensi Kepribadian \\
\hline 11 & $\begin{array}{l}\text { Bertindak sesuai dengan norma agama, hukum, sosial dan } \\
\text { kebudayaan nasional Indonesia. }\end{array}$ \\
\hline 12 & $\begin{array}{l}\text { Menampilkan pribadi yang jujur, berakhlak mulia dan teladan } \\
\text { bagi peserta didik dan masyarakat. }\end{array}$ \\
\hline 13 & $\begin{array}{l}\text { Menampilkan diri sebagai pribadi yang mantap, stabil, dewasa, } \\
\text { arif dan berwibawa. }\end{array}$ \\
\hline 14 & $\begin{array}{l}\text { Menunjukkan etos kerja, tanggung jawab yang tinggi, rasa } \\
\text { bangga menjadi guru dan rasa percaya diri. }\end{array}$ \\
\hline 15 & Menjunjung tinggi kode etik profesi guru. \\
\hline
\end{tabular}




\begin{tabular}{|c|l|}
\hline C & Kompetensi Sosial \\
\hline 16 & $\begin{array}{l}\text { Bersikap inklusif, bertindak objektif serta tidak diskriminatif } \\
\text { karena pertimbangan jenis kelamin, agama, ras, kondisi fisik, } \\
\text { latar belakang keluarga dan status sosial ekonomi. }\end{array}$ \\
\hline 17 & $\begin{array}{l}\text { Berkomunikasi secara efektif, empatik dan santun dengan } \\
\text { sesama pendidik, tenaga kependidikan, orang tua dan } \\
\text { masyarakat. }\end{array}$ \\
\hline 18 & $\begin{array}{l}\text { Beradaptasi di tempat bertugas di seluruh wilayah Republik } \\
\text { Indonesia yang memiliki keragaman sosial budaya. }\end{array}$ \\
\hline 19 & $\begin{array}{l}\text { Berkomunikasi dengan komunitas profesi sendiri dan profesi } \\
\text { lain secara lisan dan tulisan atau bentuk lain. }\end{array}$ \\
\hline D & Kompetensi Profesional \\
\hline 20 & $\begin{array}{l}\text { Menguasai materi, struktur, konsep dan pola pikir keilmuan } \\
\text { yang mendukung mata pelajaran yang diampu. }\end{array}$ \\
\hline 21 & $\begin{array}{l}\text { Menguasai standar kompetensi dan kompetensi dasar mata } \\
\text { pelajaran yang diampu. }\end{array}$ \\
\hline 22 & $\begin{array}{l}\text { Mengembangkan materi pembelajaran yang diampu secara } \\
\text { kreatif. }\end{array}$ \\
\hline 23 & $\begin{array}{l}\text { Mengembangkan keprofesionalan secara berkelanjutan dengan } \\
\text { melakukan tindakan reflektif. }\end{array}$ \\
\hline 24 & $\begin{array}{l}\text { Memanfaatkan teknologi informasi dan komunikasi untuk } \\
\text { mengembangkan diri }\end{array}$ \\
\hline
\end{tabular}

Jika dilihat dari sudut pandang lain, kompetensi profesional dan kepribadian berdimensi inside, dalam artian melekat pada jati-diri pendidik; sedangkan kompetensi pedagogik dan sosial berdimensi outside, sehingga dapat dirasakan orang lain yang berinteraksi sosial dengan pendidik.

Kompetensi pendidik seharusnya selalu diupdate dan diupgrade mengingat layanan pendidikan yang bermutu memposisikan pendidik sebagai komponen esensial dalam proses pembelajaran. Hal ini dikarenakan pendidik adalah agen perubahan yang menjadi faktor kunci untuk mengembangkan potensi peserta didik, yang pada akhirnya meningkatkan mutu pendidikan. Lebih dari itu, tuntutan masyarakat terhadap layanan pendidikan yang bermutu semakin mendorong pendidik untuk menggubah proses pembelajaran kreatif, 
inovatif, berpusat pada peserta didik serta dilandasi nilai-nilai religius dan kearifan local (Uno \&Mohamad, 2013: 152).

Adapun karakteristik pendidik yang dinilai berhasil mengembangkan pembelajaran yang efektif adalah: Pertama, respek, memahami diri sendiri dan mampu mengontrol diri. Kedua, antusias dan bergairah dalam proses pembelajaran. Ketiga, berbicara dengan jelas dan komunikatif. Keempat, memperhatikan perbedaan individual peserta didik. Kelima, memiliki banyak pengetahuan, inisiatif dan kreativitas. Keenam, menghindari sarkasme dan ejekan terhadap peserta didik. Ketujuh, tidak menonjolkan diri dan menjadi teladan bagi peserta didik (Mulyasa, 2013: 44).

Agar menjadi pendidik yang berkualitas, sejumlah teori sudah ditawarkan oleh pakar. Misalnya Munif Chatib (2014: 64) yang menjelaskan bahwa syarat mendasar menjadi pendidik adalah: bersedia untuk selalu belajar, secara teratur membuat rencana pembelajaran sebelum mengajar, bersedia diobservasi, selalu tertantang untuk meningkatkan kreativitas, dan mempunyai karakter yang baik.

Demikian halnya dengan Richard I. Arends yang menyebutkan empat atribut tingkat tinggi yang harus dimiliki pendidik efektif. Pertama, memiliki kualitas personal yang memungkinkan seorang pendidik mengembangkan interaksi sosial yang otentik dengan peserta didik, wali murid dan sesama pendidik; serta mengkreasi kelas yang demokratis dan berkeadilan sosial. Kedua, memiliki disposisi yang positif terhadap pengetahuan. Paling tidak menguasai pengetahuan yang luas menyangkut materi pelajaran, perkembangan manusia dan pembelajaran, serta pedagogi. Ketiga, memiliki koleksi daftar praktik pengajaran yang berfungsi membangkitkan motivasi, meningkatkan keterampilan dasar, mengembangkan kemampuan berpikir tingkat tinggi dan regulasi diri peserta didik. Keempat, memiliki kemampuan refleksi dan pemecahan masalah. Dia juga memandang pembelajaran sebagai proses seumur hidup (lifelong process) dan mampu mendiagnosa berbagai situasi, lalu menggunakan pengetahuan profesional yang tepat untuk meningkatkan pembelajaran peserta didik dan memperbaiki lembaga pendidikan (Arends, 2007: 19). 
Meskipun berbagai tawaran ide sudah bermunculan terkait upaya peningkatan kompetensi pendidik profesional, baik berdasarkan telaah teoretis maupun praktis, namun masih jarang ditemui telaah konseptual yang mengacu pada al-Qur'an sebagai sumber primer pendidikan Islam. Pada ruang kosong inilah penulis mengajukan gagasan menyangkut upaya peningkatan kualitas pendidik melalui studi teks al-Qur'an. Fokus kajiannya adalah peningkatan kinerja pendidik profesional. Oleh sebab itu, tulisan ini bertujuan menemukan konsep kunci etos kerja Qur'ani yang berpotensi meningkatkan kualitas keempat kompetensi pendidik profesional sebagaimana yang diamanatkan Permendiknas No. 16 Tahun 2007.

Ada tiga rumusan masalah yang akan ditelaah. Pertama, bagaimana konsep kunci etos kerja Qur'ani dalam meningkatkan kinerja pendidik profesional? Kedua, bagaimana implementasi konsep kunci tersebut dalam meningkatkan kinerja pendidik profesional? Ketiga, bagaimana tingkatan kualitas implementasi konsep kunci tersebut dalam meningkatkan kinerja pendidik profesional?

Signifikansi tulisan ini paling tidak hadir pada tiga hal. Pertama, menghadirkan gagasan baru terkait upaya peningkatan kinerja pendidik, karena didasarkan pada hasil studi teks al-Qur'an yang relatif jarang digunakan. Kedua, memopulerkan implementasi metode tafsir tarbawi (tafsir pendidikan) yang berpotensi menjadi metode baru dalam studi Islam, terutama terkait pendidikan Islam. Ketiga, memberikan nuansa normatif dan aksiologis yang Islami pada upaya peningkatan kinerja pendidik profesional di Indonesia yang mayoritas beragama Islam.

\section{Metode Penelitian}

Penelitian ini menggunakan pendekatan kualitatif dan jenis penelitian deskriptif. Mengingat penelitian ini termasuk studi teks alQur'an dengan menerapkan metode tafsir tarbawi, maka langkahlangkah metodologis-aplikatif yang penulis tempuh adalah:

a. Menetapkan topik yang dikaji secara tematik, yaitu Strategi Peningkatan Kinerja Pendidik Profesional Berbasis Etos Kerja Qur'ani. Kemudian menyusun topik tersebut dalam outline yang pas, 
sistematis, sempurna dan utuh dalam bentuk rumusan masalah dan desain penelitian.

b. Melacak dan menghimpun ayat-ayat yang berkaitan dengan topik yang ditetapkan; lalu menentukan kategori ayat-ayat Makkiyah dan Madaniyah. Selanjutnya menyusun ayat-ayat tersebut secara runtut sesuai kronologi masa turunnya, disertai pengetahuan asbab alnuzul dan munasabah.

c. Mempelajari ayat-ayat tersebut secara tematik dan menyeluruh dengan cara menghimpun ayat-ayat yang mengandung pengertian serupa, mengompromi-kan antara 'am dan khas, muthlaq dan muqayyad, mensinkronkan ayat-ayat yang tampaknya kontradiktif, menjelaskan nasikh-mansukh, sehingga semua ayat bertemu pada satu muara, tanpa perbedaan dan kontradiksi atau tindak pemaksaan terhadap sebagian ayat kepada makna-makna yang sebenarnya tidak tepat. Bila dipandang perlu, pembahasan dan uraian dilengkapi dengan Hadis, sehingga penjelasan menjadi semakin sempurna dan jelas (Rosidin, 2015: 27 - 28).

Sumber data primer penelitian ini adalah kitab tafsir al-Qur'an dan literatur tentang pendidik, sedangkan sumber sekunder berupa literatur yang relevan dengan topik.

Dalam aplikasi metode tafsir tarbawi, ada tiga teknik analisis yang digunakan. Pertama, analisis kebahasaan (lughawi). Yaitu memahami makna linguistik dari suatu term dan derivasinya secara utuh, berdasarkan penggunaan term tersebut dalam seluruh isi alQur'an. Kedua, analisis isi (tahlili). Yaitu memahami makna suatu ayat berdasarkan kitab tafsir yang relevan. Ketiga, analisis kependidikan (tarbawi). Yaitu memahami nilai-nilai pendidikan yang terkandung dalam suatu ayat dengan melibatkan sumber data primer maupun sekunder.

\section{Hasil dan Pembahasan}

Ada tiga kategori ayat yang dijadikan sebagai data penelitian. Pertama, ayat-ayat yang secara eksplisit memuat term 'allama yang berarti pengajaran. Jumlahnya ada 41 ayat sebagaimana tabel berikut ini (Al-Baqi, 2007: 576 - 591): 


\section{Tabel 2}

\section{Ayat-ayat yang Memuat Term 'Allama (Pengajaran)}

\begin{tabular}{|c|c|c|c|}
\hline No & Term & Frekuensi & Surat - Ayat \\
\hline 1 & عَلَّمَ & 4 & $\begin{array}{l}\text { al-Baqarah: 31; al-Rahman: 2; al-'Alaq: 4; } \\
5\end{array}$ \\
\hline 2 & 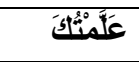 & 1 & al-Mai'dah: 110 \\
\hline 3 & 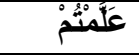 & 1 & al-Mai'dah: 4 \\
\hline 4 & عَلَمْنَّنَا & 1 & al-Baqarah: 32 \\
\hline 5 & عَلَمْنَّنِيْ & 1 & Yusuf: 101 \\
\hline 6 & 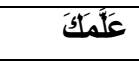 & 1 & al-Nisa': 113 \\
\hline 7 & 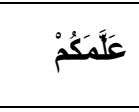 & 4 & $\begin{array}{l}\text { al-Baqarah: 239; al-Mai'dah: 4; Thaha: } \\
\text { 71; al-Syu'ara': 49; }\end{array}$ \\
\hline 8 & عَلََمْنَاُهُ & 4 & $\begin{array}{l}\text { Yusuf: 68; al-Kahfi: 65; al-Anbiya': 80; } \\
\text { Yasin: } 69\end{array}$ \\
\hline 9 & عَلَمَنَيْ & 1 & Yusuf: 37 \\
\hline 10 & عَلََمَهُ & 4 & $\begin{array}{l}\text { al-Baqarah: 251; 282; al-Najm: 5; al- } \\
\text { Rahman: } 4\end{array}$ \\
\hline 11 & لُعَلَمَنْ & 1 & al-Kahfi: 66 \\
\hline 12 & تُعَلمَمُونْ & 2 & Ali 'Imran: 79; al-Hujurat: 16 \\
\hline 13 & 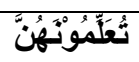 & 1 & al-Mai'dah: 4 \\
\hline 14 & 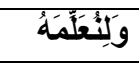 & 1 & Yusuf: 21 \\
\hline 15 & ليُعَلْمَان & 1 & al-Baqarah: 102 \\
\hline 16 & 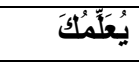 & 1 & Yusuf: 6 \\
\hline 17 & يُعَلْمُكُمْ & 3 & al-Baqarah: 151 (2x); 282 \\
\hline 18 & يُعَلْمُهُ & 2 & Ali 'Imran: 48; al-Nahl: 103 \\
\hline 19 & يُعَلَّمُهُجْ & 3 & $\begin{array}{l}\text { al-Baqarah: 129; Ali 'Imran: 164; al- } \\
\text { Jumu'ah: } 2\end{array}$ \\
\hline 20 & يُعَلْمُونْ & 1 & al-Baqarah: 102 \\
\hline 21 & عَلْمنتَ & 1 & al-Kahfi: 66 \\
\hline 22 & 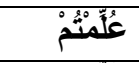 & 1 & al-An'am: 91 \\
\hline 23 & عُلْمنْنَا & 1 & al-Naml: 16 \\
\hline
\end{tabular}

Kedua, ayat-ayat yang secara eksplisit memuat term yang relevan konteks pembelajaran. Misalnya: term "membaca" dan "pena" dalam 
Surat al-'Alaq [96]: 1-5, term "nasihat" dan "debat" dalam Surat al-Nahl [16]: 125, dan sebagainya. Ketiga, ayat-ayat yang secara eksplisit maupun implisit relevan dengan empat kompetensi inti pendidik, yaitu profesional, pedagogik, kepribadian dan sosial. Misalnya perintah taat kepada Ulil Amri yang relevan dengan kompetensi profesional dalam Surat al-Nisa' [4]: 59; persiapan lahir dan batin sebelum memberikan pendidikan yang relevan dengan kompetensi pedagogik dalam Surat al-Muddatstsir [74]: 1-7; etos kerja keras yang relevan dengan kompetensi kepribadian dalam Surat al-Insyirah [94]: 5-7; perintah berinteraksi sosial yang relevan dengan kompetensi sosial dalam Surat al-Nisa' [4]: 36.

Setelah melalui tiga tahap analisis data yang terdiri dari analisis kebahasaan, isi dan kependidikan, maka hasil penelitian dibahas sesuai dengan rumusan masalah.

a. Kesadaran Diri sebagai Konsep Kunci Etos Kerja Qur'ani

Hasil analisis terhadap data ayat sampai pada simpulan bahwa "kesadaran diri" merupakan konsep kunci etos kerja Qur'ani dalam meningkatkan kinerja pendidik profesional. Intinya, peningkatan kompetensi profesional melalui kesadaran atas kewajiban asasi pendidik; peningkatan kompetensi pedagogik melalui kesadaran atas hak asasi peserta didik; peningkatan kompetensi kepribadian melalui kesadaran atas kekurangan diri sendiri; peningkatan kompetensi sosial melalui kesadaran atas kelebihan orang lain. Berikut penjelasan lebih detail terkait keempat jenis kesadaran diri tersebut.

1) Kompetensi Profesional: Kesadaran Diri atas Kewajiban Asasi Pendidik

Kesadaran diri atas kewajiban asasi pendidik berangkat dari keyakinan bahwa setiap amanat yang diemban meniscayakan tanggung jawab. Tanggung jawab tersebut berupa pelaksanaan amanat dengan penuh totalitas, tidak setengahsetengah, apalagi bertolak-belakang dengan amanat yang diemban (Q.S. al-Nahl [16]: 90-92).

Amanat yang diemban pendidik inilah yang disebut kewajiban asasi. Adapun standar kewajiban asasi pendidik diatur oleh pihak yang berwenang atau Ulil Amri. Menurut Quraish Shihab (2011: 461), Ulil Amri adalah pihak yang mewakili 
masyarakat dalam berbagai kelompok dan profesinya. Wewenang yang dimiliki oleh Ulil Amri bisa bersumber dari masyarakat maupun melalui pemerintah yang sah, yang menunjuk kelompok orang atau orang tertentu untuk menangangi suatu urusan. Jadi, dalam konteks pendidik di Indonesia, Ulil Amri yang bersumber dari pemerintah yang sah adalah Kemenag, Kemdikbud dan Kemristek. Kebijakankebijakan Ulil Amri harus ditaati, sepanjang tidak bertentangan dengan ketaatan kepada Allah SWT dan Rasulullah SAW (Q.S. alNisa' [4]: 59).

Di antara kebijakan yang harus ditaati pendidik adalah perundang-undangan yang mengatur profesi pendidik, misalnya Undang-Undang Republik Indonesia Nomor 14 Tahun 2005 tentang Guru dan Dosen. Di antara Pasal yang relevan dengan topik kewajiban asasi pendidik adalah:

Pasal 1 ayat 1: Guru adalah pendidik profesional dengan tugas utama mendidik, mengajar, membimbing, mengarahkan, melatih, menilai, dan mengevaluasi peserta didik pada pendidikan anak usia dini jalur pendidikan formal, pendidikan dasar, dan pendidikan menengah.

Pasal 1 ayat 2: Dosen adalah pendidik profesional dan ilmuwan dengan tugas utama mentransformasikan, mengembangkan, dan menyebarluaskan ilmu pengetahuan, teknologi, dan seni melalui pendidikan, penelitian, dan pengabdian kepada masyarakat.

Pasal 6: Kedudukan guru dan dosen sebagai tenaga profesional bertujuan untuk melaksanakan sistem pendidikan nasional dan mewujudkan tujuan pendidikan nasional, yaitu berkembangnya potensi peserta didik agar menjadi manusia yang beriman dan bertakwa kepada Tuhan Yang Maha Esa, berakhlak mulia, sehat, berilmu, cakap, kreatif, mandiri, serta menjadi warga negara yang demokratis dan bertanggung jawab.

Hemat penulis, kewajiban asasi pendidik tidak lepas tiga hal yang dikenal sebagai Tridharma Perguruan Tinggi. Yaitu pelaksanaan pendidikan dan pengajaran, penelitian dan 
penulisan karya ilmiah, serta pengabdian pada masyarakat. Tiga kewajiban asasi inilah yang akan ditelaah lebih jauh.

Kewajiban asasi berupa pelaksanaan pendidikan dan pengajaran harus berkonotasi positif, bukan negatif (Q.S. alBaqarah [2]: 102). Pelaksanaan penelitian dan penulisan karya ilmiah merupakan bagian dari aktivitas baca-tulis untuk menambah khazanah ilmu pengetahuan yang belum terungkap sebelumnya (Q.S. al-'Alaq [96]: 1-5). Pengabdian pada masyarakat adalah bukti nyata peran serta pendidik untuk menyebar-luaskan rahmat (Q.S. al-Anbiya' [21]: 107).

Lebih dari itu, perpaduan ketiga kewajiban asasi tersebut merepresentasikan konsep besar pendidikan Islam yang tercermin dalam Tarbiyah, Ta'lim dan Ta'dib. Tarbiyah merepresentasikan pelaksanaan pendidikan dan pengajaran, Ta'lim merepresentasikan penelitian dan penulisan karya ilmiah, sedangkan Ta'dib merepresentasikan pengabdian masyarakat.

Dari tiga kewajiban asasi di atas, penelitian dan penulisan karya ilmiah memegang peranan sentral. Maksudnya, hasil penelitian dan penulisan karya ilmiah dapat digunakan untuk kepentingan pendidikan dan pengajaran maupun pengabdian masyarakat. Berikut ini ilustrasinya:

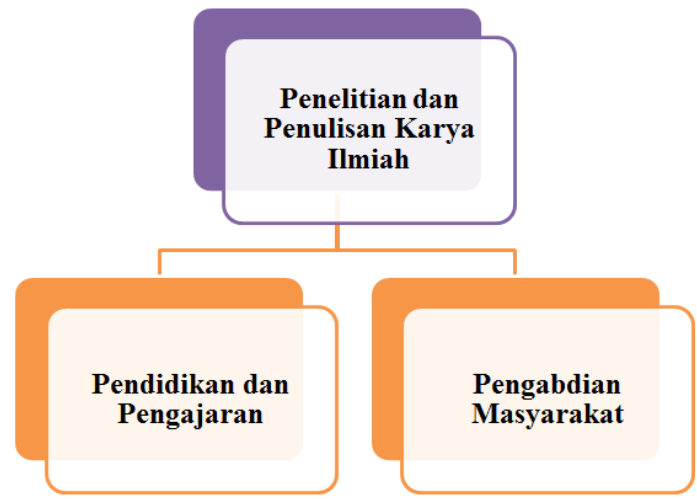

\section{Gambar 1}

Peran Sentral Penelitian dan Penulisan Karya Ilmiah 
2) Kompetensi Pedagogik: Kesadaran Diri atas Hak Asasi Peserta Didik

Hak asasi peserta didik dalam Undang-Undang RI No. 20 Tahun 2003 tentang Sistem Pendidikan Nasional (SISDIKNAS) pada Bab V Pasal 12 adalah: a) Mendapatkan pendidikan agama sesuai dengan agama yang dianutnya dan diajarkan oleh pendidik yang seagama; b) Mendapatkan pelayanan pendidikan sesuai dengan bakat, minat dan kemampuannya; c) Mendapatkan beasiswa bagi yang berprestasi yang orang tuanya tidak mampu membiayai pendidikannya; d) Mendapatkan biaya pendidikan bagi mereka yang orang tuanya tidak mampu membiayai pendidikannya; e) Pindah ke program pendidikan pada jalur dan satuan pendidikan lain yang setara; f) Menyelesaikan program pendidikan sesuai dengan kecepatan belajar masing-masing dan tidak menyimpang dari ketentuan batas waktu yang ditetapkan.

Selain hak asasi yang diamanatkan undang-undang di atas, hak asasi peserta didik seharusnya diarahkan pada pemenuhan lima kebutuhan utama manusia menurut Maqashid Syariah (tujuan-tujuan syariat Islam), yaitu kebutuhan spiritual (hifzh aldin), jasmani-ruhani (hifzh al-nafs), intelektual (hifzh al-'aql), sosial ( hifzh al-nasl) dan vokasional (hifzh al-mal). 


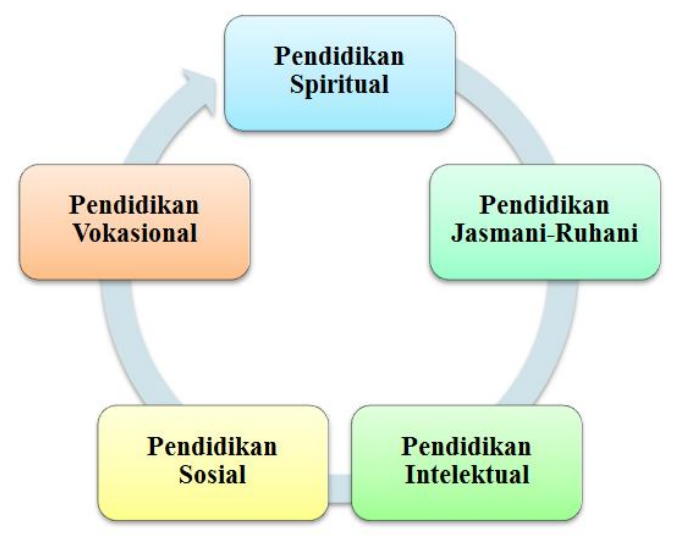

\section{Gambar 2}

\section{Pendidikan yang Menjadi Hak Asasi Peserta Didik}

Misalnya: Pendidikan spiritual diarahkan pada pengamalan nilai-nilai al-Qur'an dan al-Hikmah (Q.S. al-Jumu'ah [62]: 2). Pendidikan jasmani-ruhani diarahkan pada sehat jasmani (Surat al-Najm [53]: 5) dan suci ruhani (Q.S. Ali ‘mran [3]: 164]. Pendidikan intelektual diarahkan pada penguasaan konsep-konsep utama yang dapat dikembangkan secara mandiri oleh peserta didik (Q.S. al-Baqarah [2]: 31). Pendidikan sosial diarahkan pada keterampilan komunikasi yang dibutuhkan dalam interaksi sosial (Q.S. al-Rahman [55]: 4). Pendidikan vokasional diarahkan pada keterampilan yang berguna untuk menunjang kemandirian ekonomi (Q.S. al-Anbiya' [21]: 80).

Utamanya pendidikan dan pengajaran ditujukan pada halhal yang masih belum diketahui oleh peserta didik (Q.S. al-'Alaq [96]: 5; Surat al-Nisa' [4]: 113; Surat al-Baqarah [2]: 151, 239). Hal ini wajar karena

3) Kompetensi Kepribadian: Kesadaran Diri atas Kekurangan Diri Sendiri

Jika mengacu pada rincian kompetensi kepribadian yang tertuang dalam Permendiknas, maka kesadaran atas kekurangan 
diri sendiri dapat diorientasikan pada empat komponen utama yang disorot oleh Imam al-Ghazali dalam Ihya' Ulumiddin, yaitu ibadah, adat kebiasaan, akhlak tercela dan akhlak terpuji. Pendidik dituntut untuk terus-menerus memperbaiki kekurangan diri pada empat hal tersebut, sehingga layak menjadi teladan bagi peserta didik.

Komponen ibadah ditujukan pada perbaikan dimensi iman dan Islam. Baik yang berstatus wajib maupun sunah. Misalnya memperbaiki kualitas shalat, dari level "lalai" (Q.S. al-Ma'un [107]: 5) menuju level "rajin" (Q.S. al-Ma'arij [70]: 23) hingga akhirnya "khusyu'” (Q.S. al-Baqarah [2]: 45).

Komponen adat istiadat ditujukan pada realisasi 'urf dalam kehidupan sehari-hari. 'Urf adalah kebaikan yang memadukan nilai-nilai universal Islam dengan nilai-nilai temporal kebudayaan masyarakat. Komponen ini meliputi etika makanminum, hubungan dengan lawan jenis, kerja, hingga interaksi sosial dalam skala luas. Misalnya bergaul dengan kedua orang tua, sanak famili, tetangga, rekan dan sesama manusia sesuai dengan adat istiadat yang berlaku di masyarakat setempat, sehingga membuatnya tidak dilabeli sebagai orang yang antisosial atau sombong (Q.S. al-Nisa' [4]: 36).

Komponen akhlak tercela ditujukan pada upaya tazkiyyah atau pembersihan penyakit-penyakit hati (Q.S. al-Jumu'ah [62]: 2). Misalnya mengendalikan nafsu syahwat perut dan kemaluan; menjaga diri dari keburukan-keburukan lisan, seperti berdusta dan ghibah; meredam sikap marah, hasud dan dendam; menghilangkan sikap tamak dan kikir; tidak terbuai oleh pangkat dan popularitas; dan lain-lain.

Komponen akhlak terpuji ditujukan pada upaya meraih kebijaksanaan (hikmah) dari segenap akhlak-akhlak terpuji (Q.S. Ali 'Imran [3]: 164). Mulai dari taubat; sabar-syukur; raja'-khauf; zuhud-tawakkal; mahabbah-ridha; muhasabah-muraqabah; tafakkur-dzikir; hingga ikhlas semata-mata karena Allah SWT. 


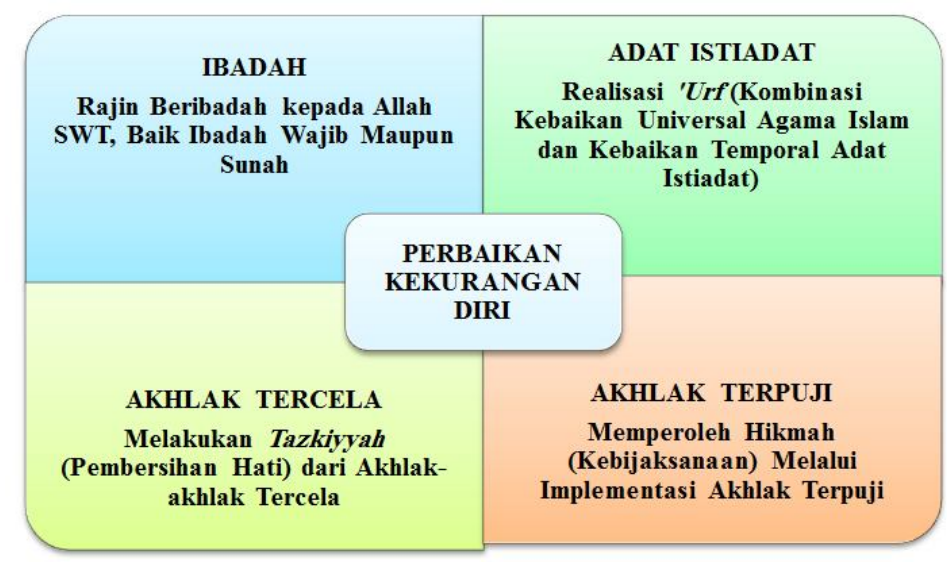

\section{Gambar 3}

\section{Dimensi-Dimensi Perbaikan Kekurangan Diri Pendidik}

4) Kompetensi Sosial: Kesadaran Diri atas Kelebihan Orang Lain

Kesadaran diri atas kelebihan orang lain diwujudkan melalui K4P, yaitu Komunikasi, Kolaborasi, Kompetisi, Kontribusi dan Prestasi.

Komunikasi dilakukan dengan tiga kategori bahasa. Pertama, berbahasa etis, melalui qaulan kariman kepada orang yang lebih dewasa (atasan), qaulan ma'rufan kepada orang yang seusia (rekan sejawat), dan qaulan layyinan kepada orang yang lebih muda (peserta didik). Kedua, berbahasa estetis, melalui qaulan tsaqilan yang secara intrinsik berupa bahasa yang ringkas, namun kaya makna (bernas) dan qaulan balighan yang secara ekstrinsik berupa bahasa yang dapat dipahami oleh mitra bicara. Ketiga, berbahasa saintis, melalui pembiasaan qaulan sadidan ketika menyampaikan ilmu pengetahuan kepada orang lain.

Kolaborasi diorientasikan pada hal-hal yang bernuansa ketakwaan dan kebaikan sosial (al-birr), bukan pada hal-hal yang bernuansa dosa dan permusuhan (Q.S. al-Ma'idah [5]: 2). 
Kompetisi ditujukan pada hal-hal yang bernuansa kebaikan universal (Q.S. al-Baqarah [2]: 148). Kontribusi diarahkan pada upaya pemberian manfaat dan pencegahan mudarat melalui mekanisme Amar Ma'ruf Nahy Munkar (Q.S. Ali 'Imran [3]: 104). Prestasi membidik terciptanya kondisi masyarakat ideal yang memadukan antara kesejahteraan hidup dengan kualitas spiritual tingkat tinggi (Q.S. Saba' [34]: 15).

PRESTASI

\section{KOMPETISI}

\section{KONTRIBUSI}

KOLABORASI

\section{KOMUNIKASI}

\section{Gambar 4 \\ Manifesitasi Kesadaran Diri atas Kelebihan Orang Lain}

b. Implementasi Kesadaran Diri dalam Meningkatkan Kinerja Pendidik Profesional

Strategi implementasi kesadaran diri dalam meningkatkan kinerja pendidik profesional bersifat teologis (iman), teoretis (ilmu), praktis (amal) dan moralistis (akhlak).

1) Strategi Implementasi Kesadaran Diri dalam Tataran Teologis

Pada tataran teologis, pendidik dituntut untuk memahami hakikat Allah SWT, manusia dan alam semesta; serta relasi antara ketiganya dalam konteks kehidupan dunia dan akhirat.

Dalam teologi pendidikan Islam disebutkan bahwa tujuan utama pendidikan Islam adalah mencetak insan kamil (manusia 
paripurna). Indikatornya adalah: dalam relasinya dengan Allah SWT, dia menjadi hamba Allah yang rajin beribadah (Q.S. alDzariyat [51]: 56); dalam relasinya dengan sesama manusia (diri sendiri maupun orang lain), dia mampu mengaktualisasikan seluruh potensi terbaiknya yang bersifat jasmani maupun ruhani (Q.S. al-Tin [95]: 4); dalam relasinya dengan alam semesta, dia menjadi khalifah Allah yang bertanggung-jawab melestarikan dan memakmurkan alam semesta (Q.S. al-Baqarah [2]: 30). Tiga hal itulah yang menjamin terwujudnya kehidupan yang berkualitas, baik di dunia maupun di akhriat (Q.S. al-Baqarah [2]: 201).

Relevan dengan itu, agama memberikan dua kategori petunjuk kehidupan. Pertama, petunjuk yang bersifat permanen dan terperinci yang tidak dibutuhkan campur tangan pemikiran manusia untuk pengaturannya dan tidak akan mengalami perubahan dalam kondisi dan situasi apapun. Kedua, petunjuk yang bersifat global atau umum dan dalam hal ini manusia diberi wewenang untuk memikirkannya sesuai dengan kondisi dan situasi masyarakat. Inilah yang disebut spiritualisasi kehidupan, yaitu menyelaraskan nilai-nilai agama (Islam) dengan perkembangan budaya manusia (Shihab, 2013: 367).

2) Strategi Implementasi Kesadaran Diri dalam Tataran Teoretis

Pada tataran teoretis, pendidik dituntut untuk memberdayakan saluran-saluran ilmu pengetahuan yang dimiliki, yaitu pancaindra, akal dan hati. Wujudnya adalah $\mathrm{p}$ eningkatan kualitas keilmuan melalui pengalaman empiris, logis dan intuitif (Q.S. al-Nahl [16]: 78).

Pengalaman empiris diperkaya melalui observasi (Q.S. alAn'am [6]: 11) Pengalaman logis dikembangkan melalui literasi, yaitu membaca dan menulis (Q.S. al-'Alaq [96]: 1-5). Sedangkan pengalaman intuitif diasah melalui amal-amal yang mencerminkan ketakwaan kepada Allah SWT (Q.S. al-Baqarah [2]: 282). Perpaduan antara kelima pengalaman itulah yang membuat seseorang berhak menyandang status sebagai Ulama (Q.S. Fathir [35]: 28) 
Dalam bahasa ilmiah, pancaindra merupakan sensor atau input, sedangkan baik-buruknya output tergantung pada pemrosesnya, yaitu hati. Adapun akal hanyalah asisten. Hati berfungsi menentukan mana yang benar dan mana yang salah, sedangkan akal membedakan mana yang baik dan mana yang buruk. Lebih dari itu, al-Ghazali menyatakan bahwa manusia bergerak dengan tiga pertimbangan yang meliputi kualitas baik (rasional), kualitas benar (spiritual) dan kualitas nyaman (emosional). Pembelajar yang ideal adalah yang mendudukkan kualitas spiritual (hati) sebagai raja, kualitas rasional (akal) sebagai asisten, sedangkan kualitas emosional (nafsu) sebagai petugas.

3) Strategi Implementasi Kesadaran Diri dalam Tataran Praktis

Implementasi kesadaran diri dalam tataran praktis mengacu pada realisasi etos kerja keras (hard work), etos kerja cerdas (smart work), etos kerja berkualitas (quality work) dan etos kerja ikhlas (ikhlas work).

Etos kerja keras diwujudkan melalui sikap gigih tak kenal lelah (Q.S. al-Insyirah [94]: 5-7). Etos kerja cerdas diwujudkan dengan melakukan segenap aktivitas berdasarkan ilmu pengetahuan yang bersifat empiris, logis, atau intuitif; bukan mengacu pada taklid buta, meskipun sudah mentradisi (Q.S. alIsra' [17]: 36). Etos kerja berkualitas mengacu pada totalitas kerja dengan memadukan ilmu pengetahuan dan kebijaksanaan (Q.S. Yusuf [12]: 22). Etos kerja ikhlas dilakukan dengan cara "mengatas-namakan Allah", baik pada saat pra, proses maupun pasca pekerjaan (Q.S. al-'Alaq [96]: 1).

Secara garis besar, al-Qur'an memerintahkan manusia agar memanfaatkan waktu semaksimal mungkin. Bahkan al-Qur'an tidak hanya memerintahkan asal kerja, melainkan harus bekerja dengan sungguh-sungguh dan sepenuh hati. Surat al-'Ashr dan dua ayat terakhir Surat al-Insyirah menguraikan secara gamblang mengenai tuntunan tersebut. Rasulullah SAW juga mengingatkan agar umatnya meneladani Allah SWT dalam sifat dan sikap-Nya sesuai dengan kemampuannya sebagai makhluk. 
Salah satu yang patut diteladani adalah "Setiap saat, Dia (Allah) berada dalam kesibukan (Q.S. al-Rahman [55]: 29) (Shihab, 2014: 731 - 737).

4) Strategi Implementasi Kesadaran Diri dalam Tataran Moralistis

Implementasi kesadaran diri pada tataran moralistis mengacu pada konsep Tilawah, Tazkiyah, Hikmah dan Uswah.

Tilawah fokus pada terlaksananya kewajiban asasi pendidik (Q.S. al-Jumu'ah [62]: 2). Kekurangan diri dalam melaksanakan kewajiban asasi tersebut diperbaiki melalui upaya penyucian ruhani atau Tazkiyyah (Q.S. al-Jumu'ah [62]: 2). Melalui Tazkiyyah, akan muncul Hikmah (kebijaksanaan) yang merupakan intisari dari pengalaman teoretis dan praktis (Q.S. alBaqarah [2]: 251). Pada saat itulah seorang pendidik layak mendapat status sebagai Uswah (teladan yang terpuji) bagi para peserta didik maupun sesama pendidik (Q.S. al-Ahzab [33]: 21).

Bagi umat muslim, teladan utama (uswah hasanah) adalah Rasulullah SAW. Beliau telah melakukan Tilawah dengan membacakan ayat-ayat Allah SWT yang menunjukkan kekuasaan dan keesaan-Nya. Lalu beliau melakukan membersihkan umatnya dari kepercayaan yang rusak dan menggantinya dengan pemikiran yang benar dan matang hingga membentuk sebuah peradaban. Selanjutnya beliau mengajarkan al-Qur'an dan alSunnah yang pada akhirnya melahirkan para ulama', orang bijak, pemimpin dan pakar pakar di berbagai cabang ilmu pengetahuan dan peradaban. Jadi, melalui kombinasi cahaya Islam, ilmu alQur'an dan pengetahuan kehidupan, Rasulullah SAW berhasil mengantarkan umat muslim menjadi umat yang berperadaban unggul dibanding umat-umat lainnya (Al-Zuhaili, 1991: 139).

Seluruh strategi implementasi kesadaran diri di atas, dapat divisualisasikan dengan patron tiga komponen pendukung yang dibutuhkan untuk merealisasikan kesadaran diri pada tingkatan tertinggi. Berikut visualisasinya: 

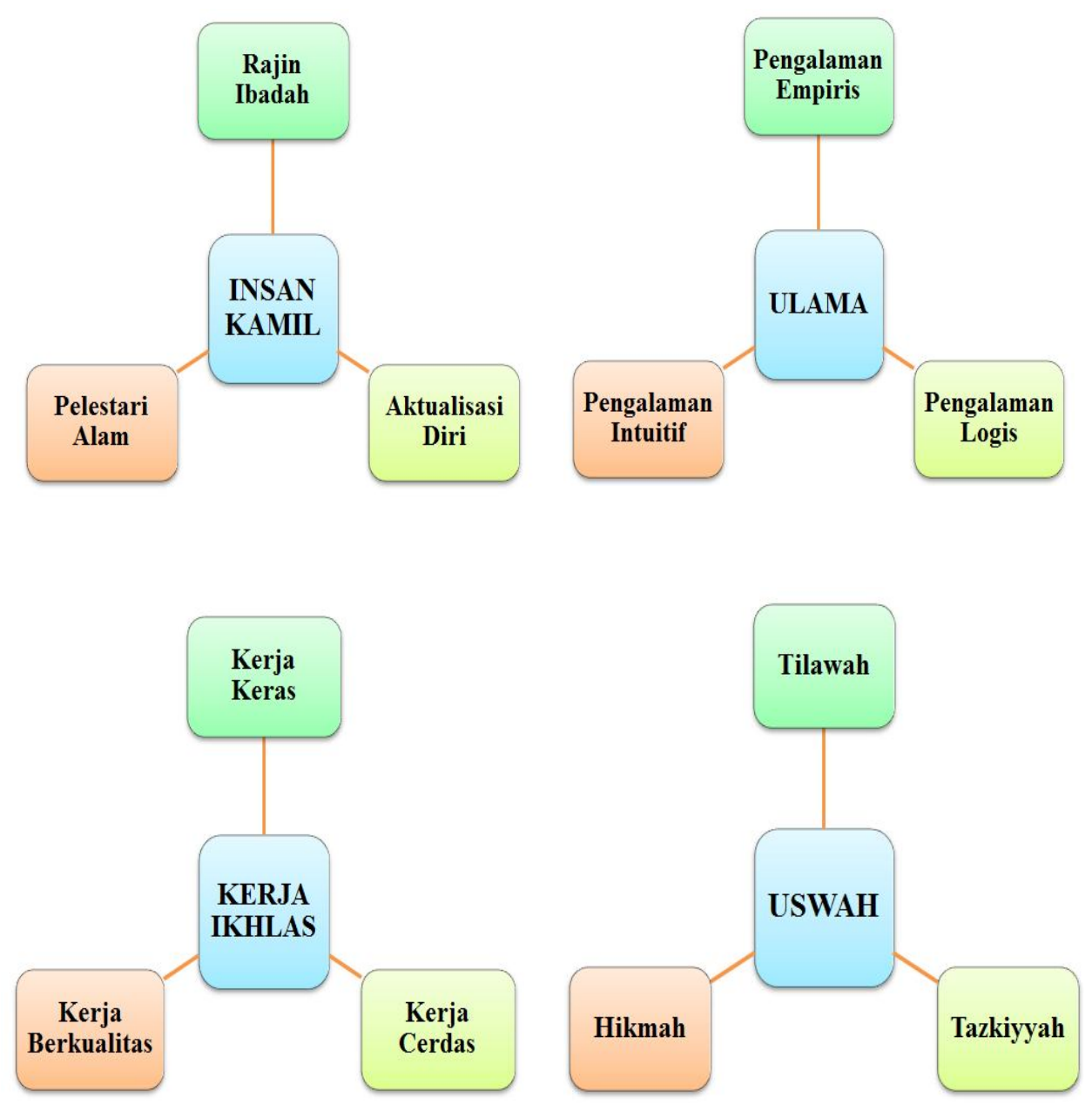

Gambar 4

Pola Strategi Implementasi Kesadaran Diri Pendidik

c. Tingkatan Kualitas Implementasi Kesadaran Diri dalam Meningkatkan Kinerja Pendidik Profesional

Ada tiga tingkatan kualitas implementasi kesadaran diri dalam meningkatkan kinerja pendidik profesional, yaitu di bawah standar 
(zhalim); sesuai standar (muqtashid); dan di atas standar (sabiq) (Q.S. Fathir [35]: 32).

1) Tingkatan Kualitas di Bawah Standar

Pendidik yang menempati tingkatan kualitas di bawah standar adalah pendidik yang tidak memenuhi kewajiban asasinya, sedikit maupun banyak. Misalnya: Pendidik memberikan pendidikan dan pengajaran tidak sesuai dengan durasi waktu yang menjadi kewajiban asasinya dalam jadwal mengajar, semisal telat masuk kelas atau cepat pulang sebelum waktunya, tanpa ada alasan atau uzur yang dapat ditoleransi.

2) Tingkatan Kualitas Sesuai Standar

Pendidik yang menempati kualitas sesuai standar adalah pendidik yang memenuhi kewajiban asasinya sesuai dengan standar normal. Misalnya: Pendidik yang mengadakan penelitian dan penulisan karya ilmiah sesuai dengan standar minimal yang diminta oleh pihak pemerintah. Jika pemerintah menuntut dua karya ilmiah per semester, dia pun hanya menghasilkan dua karya ilmiah saja.

3) Tingkatan Kualitas di Atas Standar

Pendidik yang menempati kualitas di atas standar adalah pendidik yang "selalu terdepan" dalam pelaksanaan kewajiban asasinya. Misalnya: Pendidik yang mengadakan pengabdian masyarakat melampaui standar normal yang diminta oleh pemerintah. Dia bukan sekedar berkontribusi kepada masyarakat, melainkan sudah pada tingkatan menjadi agen transformasi masyarakat melalui mobilitas sosial. Seperti meningkatkan level literasi anggota masyarakat yang semula mayoritas hanya puas mengenyam pendidikan tingkat menengah, bertransformasi menjadi antusias untuk melanjutkan ke jenjang pendidikan tinggi.

Evaluasi tingkatan kualitas implementasi kesadaran diri pendidik tidaklah bersifat global, melainkan spesifik. Misalnya: Seorang pendidik memiliki kualitas di bawah standar pada kompetensi pedagogik, namun memiliki kualitas di atas standar pada kompetensi sosial. Demikian halnya, seorang pendidik memiliki kualitas di atas standar pada tataran teoretis, namun memiliki kualitas di bawah 
standar pada tataran praktis. Oleh sebab itu, penulis mengajukan contoh evaluasi tingkatan kualitas implementasi kesadaran diri berdasarkan pada indikator-indikator yang dibahas pada subbab sebelumnya.

Tabel 3

Tabel Evaluasi Tingkatan Kualitas Implementasi Kesadaran Diri

\begin{tabular}{|l|c|c|c|c|c|c|c|c|c|c|c|c|}
\hline & $\begin{array}{c}\text { TATARAN } \\
\text { TEOLOGIS } \\
\text { Insan } \\
\text { Kamil }\end{array}$ & \multicolumn{2}{|c|}{$\begin{array}{c}\text { TATARAN } \\
\text { TEORETIS } \\
\text { Ulama }\end{array}$} & \multicolumn{2}{c|}{$\begin{array}{c}\text { TATARAN } \\
\text { PRAKTIS } \\
\text { Ikhlas }\end{array}$} & \multicolumn{2}{|c|}{$\begin{array}{c}\text { TATARAN } \\
\text { MORALISTIS } \\
\text { Uswah }\end{array}$} \\
\hline & 1 & 2 & 3 & 4 & 5 & 6 & 7 & 8 & 9 & 10 & 11 & 12 \\
\hline TINGGI & & & & & & & & & & & & \\
\hline SEDANG & & & & & & & & & & & & \\
\hline RENDAH & & & & & & & & & & & \\
\hline
\end{tabular}

Keterangan:

\begin{tabular}{|l|l|l|l|}
\hline 1. Rajin Ibadah & $\begin{array}{l}\text { 4.Pengalaman } \\
\text { Empiris }\end{array}$ & 7. Kerja Keras & 10. Tilawah \\
\hline $\begin{array}{l}\text { 2. Aktualisasi } \\
\text { Diri }\end{array}$ & $\begin{array}{l}\text { 5.Pengalaman } \\
\text { Logis }\end{array}$ & 8. Kerja Cerdas & Tazkiyyah \\
\hline $\begin{array}{l}\text { 3.Pelestari } \\
\text { Alam }\end{array}$ & $\begin{array}{l}\text { 6.Pengalaman } \\
\text { Intuitif }\end{array}$ & $\begin{array}{l}\text { 9. Kerja } \\
\text { Berkualitas }\end{array}$ & 12. Hikmah \\
\hline
\end{tabular}

\section{Kesimpulan}

Ada tiga simpulan penelitian ini. Pertama, "kesadaran diri" merupakan konsep kunci etos kerja Qur'ani dalam meningkatkan kinerja pendidik profesional. Detailnya, peningkatan kompetensi profesional melalui kesadaran atas kewajiban asasi pendidik; peningkatan kompetensi pedagogik melalui kesadaran atas hak asasi peserta didik; peningkatan kompetensi kepribadian melalui kesadaran atas kekurangan diri sendiri; peningkatan kompetensi sosial melalui kesadaran atas kelebihan orang lain. Kedua, strategi implementasi kesadaran diri dalam meningkatkan kinerja pendidik profesional bersifat teologis (iman), teoretis (ilmu), praktis (amal) dan moralistis 
Rosidin - Strategi Peningkatan Kinerja Pendidik Profesional Berbasis Etos Kerja Qur'ani

(akhlak). Ketiga, ada tiga tingkatan kualitas implementasi kesadaran diri, yaitu di bawah standar (zhalim); sesuai standar (muqtashid); dan di atas standar (sabiq). 


\section{DAFTAR PUSTAKA}

Arends, R.I. 2007. Learning to Teach. New York: Mc-Graw Hill.

al-Baqi, M.F.A. 2007. al-Mu'jam al-Mufahras li Alfazh al-Qur'an al-Karim. Kairo: Dar al-Hadits.

Chatib, M. 2014. Gurunya Manusia. Bandung: Kaifa.

McNergney, R. F. \& Carrier, C. A. 1981. Teacher Development. New York: McMillan Publishing.

Muhaimin. 2011. Pemikiran dan Aktualisasi Pengembangan Pendidikan Islam. Jakarta: Rajawali Pers.

Mulyasa, E. 2013. Pengembangan dan Implementasi Kurikulum 2013. Bandung: PT. Remaja Rosdakarya.

Rosidin. 2015. Metodologi Tafsir Tarbawi. Jakarta: Amzah.

Shihab, M.Q. 2011. Tafsir al-Mishbah: Pesan, Kesan dan Keserasian alQur'an [Volume 2].Jakarta: Lentera Hati.

Shihab, M.Q. 2013. Membumikan al-Qur'an: Fungsi dan Peran Wahyu dalam Kehidupan Bermasyarakat. Bandung: Mizan.

Shihab, M.Q. 2014. Wawasan al-Qur'an: Tafsir Tematik Atas Pelbagai Persoalan Umat. Bandung: Mizan.

Tim Tafsir Ilmiah Salman ITB. 2014. Tafsir Salman: Tafsir Ilmiah Juz 'Amma. Bandung: Mizan.

Uno, H.B. \& Mohamad, N. 2013. Belajar dengan Pendekatan Pailkem: Pembelajaran Aktif, Inovatif, Lingkungan, Kreatif, Menarik. Jakarta: Bumi Aksara. 
Rosidin - Strategi Peningkatan Kinerja Pendidik Profesional Berbasis Etos Kerja Qur'ani

al-Zuhaili, W. 1991. al-Tafsir al-Munir: fi al-'Aqidah wa al-Syari’ah wa al-Manhaj. Beirut: Dar al-Fikr al-Mu'ashir. 
Rosidin - Strategi Peningkatan Kinerja Pendidik Profesional Berbasis Etos Kerja Qur’ani 